\title{
Toward Sustainability in Concrete Industry by Using Of Solid Wastes from Palm Oil Industry
}

\author{
Alireza Javadi Pordesari ${ }^{1}$, Salmaliza Salleh², Payam Shafigh ${ }^{3}$ and Hilmi Bin Mahmuda1 \\ ${ }^{1}$ Department of Civil Engineering, Faculty of Engineering, University of Malaya, 50603 Kuala Lumpur, Malaysia \\ ${ }^{2}$ Faculty of Engineering and Built Environment, SEGi University, Kota Damansara, 47810 Petaling Jaya, Selangor, Malaysia \\ ${ }^{3}$ Department of Building Surveying, Faculty of Built Environment, University of Malaya, 50603 Kuala Lumpur, Malaysia
}

\begin{abstract}
Nowadays, one of the most important construction materials is concrete. By the advances of the industries in the urban areas, concrete is considered as one of the highest demands. As a result, the large amount of unprocessed materials is needed for making concrete. In the meantime, the agricultural wastes and solid material disposal are giving serious damages to the environment. As a result, by employing the agricultural wastes as a cementitious material, the undesirable impacts of the concrete industry to the environment will be dramatically decreased. That's because the source of these newly developed concretes is both reliable and environmental friendly. In this study, the utilization of agricultural wastes as a complementary cementitious material for producing the concrete is explained. In addition, it discusses the possibility of deploying the agricultural wastes by considering their engineering, physical and chemical properties. In addition, the successful use of agricultural wastes from oil palm industry such as oil palm shell, palm oil fuel ash and palm oil fibre in the concrete mixture was reported.
\end{abstract}

Keywords: Agricultural waste materials, Oil Palm industry, Oil palm fibre, Oil palm shell, Palm oil fuel ash

\section{Introduction}

It's almost about hundreds of years cement and concrete has been used in buildings, there are also evidences showing that Portland cement has been used for hundreds of years. What makes concrete standing in the first place among other materials is that the whole constituents of it can be chosen and the one, using it, is able to develop and improve the characteristics of each constituent and finally form the most developed hard-wearing impermeable material [1]. The amount of concrete production claims this truth that it is the most significant material used in buildings [2]. There is no doubt that there is a steep increase in population and by the end of the $21^{\text {st }}$ century 11 billion people will have been living on the Earth, and that's clear enough that the more population on the Earth, the more common goods and services are needed [3]. As a result it has been thought that about 18 billion tons of concrete is needed by the year 2050 [4]. Here again can be concluded the more concrete and cement going to be produced, the more natural resources is used. What has been discussed the most in the past decade is that green issue needs to be considered in every aspects of life, and the buildings are not exceptions. The construction material of building have the most impact on the Green Building Rating (GBR). Here it should be considered that there are several important factors which make concrete look less compatible with the environmental inquiries of the modern construction industry which are $\mathrm{CO}$ emission during the process of Portland Cement production, the amount of energy we dedicate to it, natural resources used such as water, aggregate and fillers which are widely used in the formation process of concrete.

Ramezanianpour et al. (2009) clarified this fact that what we are using as concrete nowadays is not sustainable at all, but using industrial and agricultural waste constituents may lead us to the point the industry will be more friendly and sustainable [ $\underline{5}$ ]. According to this debate some sort of materials can be named such as fly ash, recycled concrete, recycled plastics, silica fume, Grand Granulated Blast Furnace Slag (GGBFS) which have been used several years as important concrete production constituents $[\underline{2}, \underline{6}]$. There are some other found facts nowadays that show agricultural solid wastes are being used in both structural and non-structural concrete. Among the oil palm industry's agricultural wastes oil palm shell, palm oil fuel ash and palm oil fiber can be seen. Using other replaceable conventional 
materials such as agricultural solid wastes as aggregate in concrete instead of typical ones (sand as fine and gravel as coarse) which take three fifths to four fifths of the concrete's volume [7], helps in saving energy and natural resources as well as material cost reduction. Parallel to this strategy the problem of the wastes after the demolition of concrete structures which means saving environment is being overcome $[\underline{5}, \underline{8}]$. The research on the area of agricultural waste utilization in concrete construction is quite a new topic. The increment of research on this area encourages the construction industries to use these concretes in their projects. In this research, the agricultural solid wastes produced from oil palm industry are used tested to construct the concretes. In addition, green building rating system, environmental sustainability and the relations between concretes with similar characteristics are discussed. Recognition of these agricultural wastes by both civil and agricultural engineers made it possible to use these materials in construction and some specific industries too. Moreover, by using these materials, the environmental sustainability of concrete's manufactures will be improved.

\section{Agricultural wastes from oil palm industry}

Malaysia, Indonesia, Thailand and Nigeria are the countries that have oil palm industry as one of their main agro-industry which Malaysia and Indonesia are considered as the top two countries in palm oil production. The crude palm oil produced by Malaysia is over 7 million tons a year [9]. The world palm oil production in 2011 is shown in Figure. 1 [10]. The amount of solid waste produced during the palm fruit processing plants is considered as one of the major drawbacks of this process. As an instance, Malaysia has the highest amount of solid waste produced in a year which is 47 million tons followed by Indonesia with 40 and Thailand with 3.5 million tons of solid waste production annually. Oil palm bunches; palm fibre and fruit shells are the solid wastes. Moreover, the above mentioned countries produce over 8 million tons of oil palm shell in a year [11].

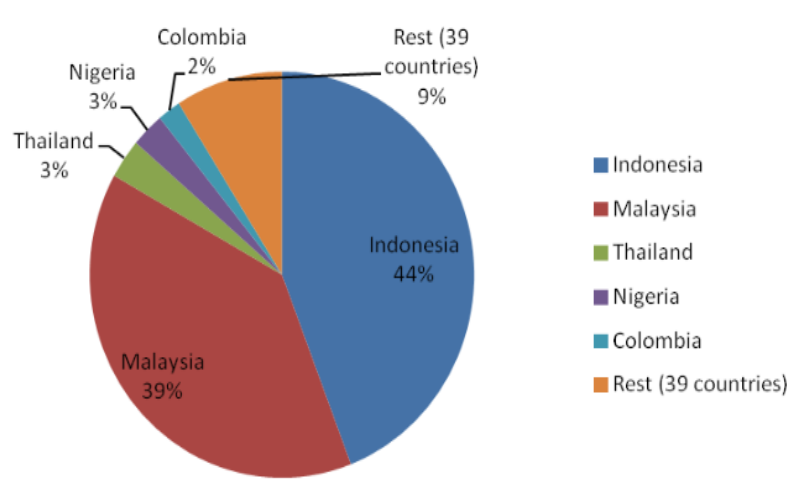

Figure 1. World palm oil production [10].

\subsection{Oil palm shell (OPS)}

The palm shell's shape can be angular or polygonal based on the breaking pattern of the nut and its oil color varies [12]. The attributes of the OPS is shown in Table 1. According to the table, the OPS has the density similar to the other lightweight aggregates while its weight is about $60 \%$ less as compared to the conventional coarse aggregates [13-15]. In addition, in comparison with conventional coarse aggregates, the OPS have about $80 \%$ lower Los Angeles abrasion value [16]. Therefore, such features and properties make OPS aggregates resistance to wear and due to its low impact and crushing values, it makes them absorbance to shock [17].

Table 1. Properties of the crushed granite (conventional aggregate), Oil palm shell and Coconut shell (agricultural waste) in detail as follows [14, 15, 17-20].

\begin{tabular}{lccc}
\hline \multicolumn{1}{c}{ Properties } & Oil Palm Shell & Crushed granite & Coconut shell \\
\hline Specific gravity & $1.17-1.37$ & $2.60-2.70$ & $1.05-1.2$ \\
\hline $\begin{array}{l}\text { Bulk density (uncompacted) } \\
(\mathrm{kg} / \mathrm{m} 3)\end{array}$ & $510-550$ & 1300 & - \\
\hline Bulk density (compacted) $(\mathrm{kg} / \mathrm{m} 3)$ & $590-600$ & $1420-1470$ & 650 \\
\hline Void ratio (uncompacted) $(\%)$ & 63 & 52 & - \\
\hline Void ratio (compacted) $(\%)$ & 57 & 47 & - \\
\hline 24 h water absorption $(\%)$ & $21-33$ & $<1$ & 24 \\
\hline Aggregate impact value $(\%)$ & $4-8$ & $13-17$ & 2.58 \\
\hline Aggregate crushing value $(\%)$ & $5-10$ & 20 & 1.63 \\
\hline Los Angeles abrasion value $(\%)$ & $3-5$ & 24 & - \\
\hline Flakiness index $(\%)$ & 65 & 25 & $-15-8 \mathrm{~mm}$ \\
\hline Shell thickness $(\mathrm{mm})$ & $2-8$ & - & -
\end{tabular}


The shells have smooth concave and convex faces with sharp and spiky broken edges. The initial start of deployment of lightweight aggregates for making lightweight concretes was by a Malaysian and Nigerian researchers in $1984[12,21]$. In many of the studies, the compressive strength of the OPS lightweight concrete with $20 \%$ to $25 \%$ lower density as compared to the Normal Weight Concretes (NWC) and in presence or absence of the cementitious materials is within the normal bounds of the compressive strength of the structural lightweight concretes (25 to $35 \mathrm{MPA})[\underline{14}, \underline{15}$, $\underline{19}, 20]$. Yet, it is still likely to enhance the compressive strength of the OPS lightweight concrete to 53 and 56 MPA in 28-day and 56-day tests [22, 23]. It is quite important to enhance the compressive strength of the concrete making use of an aggregate such as OPS with acceptable strength as the design and making a concrete structure is fully dependable on the compressive strength [23]. Besides, due to the high applicability and environmental friendly of the usage of the waste materials, the construction industry will be encouraged to apply these materials in their projects.

There are many articles and researches explaining and analyzing various mechanisms such as the use of Old OPS, Crushed OPS and OPS with smaller maximum of coarse aggregate for the production of the high strength OPS [23-25]. High compressive strength can be achieved by the Old OPS since there is no fibre on the OPS surface which accordingly improves the OPS and cement matric bond. On the other hand, crushing old OPS and diminishing the highest possible size of coarse OPS aggregate can be counted as another mechanism. Tough physical bond with hydrated cement are the main characteristics of the crushed OPS. The strong bond of the crushed OPS is because of the decreased in smooth surface of the OPS and due to crinkling of the large sizes of OPS aggregates, the total surface of the broken edges are increased. Moreover, the compressive strength increases by using smaller size of OPS aggregate which enhances the bond between the aggregate and the paste. The OPS aggregates in different states and the chosen mix proportions of OPS concrete with normal and high strengths are shown in Figure 2 and Table 2 respectively [26]. The size of the OPS (as coarse aggregate) in all of the OPS lightweight concretes with normal strength is $9.5 \mathrm{~mm}$ while is it $8 \mathrm{~mm}$ for high strength OPS production.

According to the literature [12], splitting tensile strength, flexural strength and modulus of elasticity as the mechanical properties of OPS concrete at the same compressive strength, are lower as compared to lightweight aggregate concretes made from artificial or natural lightweight aggregates. But it has been proved [24] that the compressive strength, splitting tensile and flexural strength enhance significantly by including steel fibre into OPS concrete. The steel fibre OPS concrete's splitting tensile/compressive strength ratio is within normal weight concrete and its flexural strength is similar to artificial lightweight aggregate concrete. The previous studies showed that the OPS concrete has significantly lower modulus of elasticity in comparison with the normal weight concrete. However, the OPS concrete's modulus of elasticity can be further improved to the normal weight concrete ranges by deploying certain methods which are contingent upon the use of old OPS and old crushed OPS [24, 25]. Teo et al. (2010) have analyzed the OPS structural lightweight concrete's durability properties under different curing conditions. They revealed that both OPS structural lightweight concretes and conventional lightweight concretes are having similar durability properties. They reported that OPS concrete requires proper curing to attain superior durability over the conventional lightweight concretes. In addition, they suggest that the least possible period of moist curing must be done for 7 continuous days [27]. Besides, a comparison between bond properties of OPS concrete and normal weight concrete [28] showed that the OPS concrete's bond stress was $86 \%$ of the corresponding normal weight concrete, however, the OPS concrete had 2.5 times higher bond stress as an ultimate value in comparison with the theoretical values determined according to the BS 8110 [29]. Moreover, the flexural and shear behaviour of reinforced and unreinforced concrete beams constructed from OPS were tested and examined where in low reinforcement ratio, the reinforced concrete beams fulfilled the expectations in serviceability requirements with low reinforcement ratio of the BS 8110 code, [30]. By comparing the ultimate moments and predicted moments of the OPS reinforced concrete beams with $3.14 \%$ reinforcement ratio, it is concluded that the OPS reinforced concrete performed $4 \%$ to $35 \%$ ultimate moments. But if the beam's reinforcement ratio increases to $3.90 \%$, then the ultimate moment's capacity will be underestimated by BS 8110 by about $6 \%$. Hence, it was suggested that if the reinforcement ratio is greater than $3.14 \%$, then larger depth for OPS concrete beam to be applied. The research conducted by Ahmed and Sobuz (2011) indicates that the flexural behaviour of beams produced from OPS and its theoretical results are having close outcomes [31]. Additionally, an adequate shear behavior of OPS concrete beams is described [31, $\underline{32}]$. It should be highlighted that according to Alengaram et al. (2011), the overall flexural behavior of reinforced OPS concrete beams are similar to the equivalent beams produced from normal weight concrete [33]. 


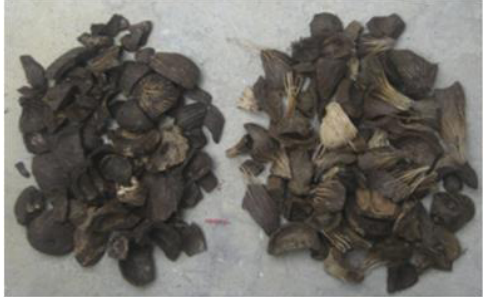

(a)

(b)

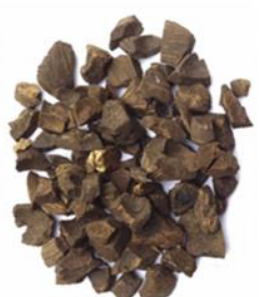

(c)

Figure 2. Oil palm shell grains in different conditions. (a): old, (b): fresh, and (c): crushed from large size old OPS [26].

Table 2. Selected mix proportion and properties of oil palm shell lightweight concrete

\begin{tabular}{|c|c|c|c|c|c|c|}
\hline \multicolumn{2}{|c|}{ Mix no } & 1 & 2 & 3 & 4 & 5 \\
\hline \multirow{8}{*}{$\begin{array}{l}\text { Mix proportion } \\
(\mathrm{kg} / \mathrm{m} 3)\end{array}$} & Cement & 360 & 480 & 550 & 480 & 510 \\
\hline & Silica fume & 0 & 0 & 0 & 0 & 0 \\
\hline & Fly ash & 0 & 0 & 0 & 0 & 0 \\
\hline & $\begin{array}{l}\text { Super } \\
\text { Plasticizer } \\
(\%)\end{array}$ & 1.8 & 1 & 1.1 & 1.5 & 1.4 \\
\hline & $\begin{array}{l}\text { Water } \\
\text { to cement }\end{array}$ & 0.45 & 0.41 & 0.31 & 0.38 & 0.38 \\
\hline & Oil palm shell & 380 & 370 & 330 & 300 & 310 \\
\hline & $\begin{array}{l}\text { Conventional } \\
\text { Coarse } \\
\text { Aggregate (granite) }\end{array}$ & 210 & 0 & 180 & 0 & 0 \\
\hline & $\begin{array}{l}\text { Fine } \\
\text { Aggregate }\end{array}$ & 830 & 820 & 710 & 1050 & 850 \\
\hline \multicolumn{2}{|c|}{ Fresh Property (slump, mm) } & 33 & 7 & 205 & 50 & 60 \\
\hline \multicolumn{2}{|c|}{ Density $(\mathrm{kg} / \mathrm{m} 3)$} & $1910^{a}$ & $1900^{a}$ & $1980^{a}$ & $1990^{c}$ & $1960^{b}$ \\
\hline \multicolumn{2}{|c|}{$\begin{array}{l}\text { 28-Day cube compressive Strength } \\
\text { (MPA) }\end{array}$} & 34 & 29 & 53 & 47 & 28 \\
\hline \multicolumn{2}{|l|}{ Reference } & $\begin{array}{l}\text { Shafigh et al. } \\
{[\underline{12}]}\end{array}$ & $\begin{array}{l}\text { Mannan and } \\
\text { Ganapathy } \\
{[13]}\end{array}$ & $\begin{array}{l}\text { Shafigh et } \\
\text { al. }[\underline{23}]\end{array}$ & $\begin{array}{l}\text { Shafigh et } \\
\text { al. [를 }\end{array}$ & $\begin{array}{l}\text { Teo et al. } \\
{[\underline{34}]}\end{array}$ \\
\hline
\end{tabular}

\footnotetext{
a Demolded density.

$\mathrm{b}_{\text {Air dry density. }}$

c Oven dry density.
}

\subsection{Palm oil fuel ash (POFA)}

Tangchirapat et al. (2009) expressed that Oil palm fuel ash (POFA) is an agro-waste ash produced from palm oil remainders like palm fibre and shells. These wastes are burnt at 800 to $1000 \mathrm{C}$ of temperature in order to use its produced steam as the purpose of generating electricity in biomass thermal power plants. There are $15 \%$ of shell and $85 \%$ of fibre in residue of the oil palm. As for the energy production, a boiler is used to burn the empty fruits which basically produce $5 \%$ ash as weight as solid waste. There is a huge pollution affecting the environment due to the production of the solid wastes and ashes. Hence, a possible practical solution must be given to resolve the land-fitting, pollution and high cost of material constructions. Due to the high cost of waste disposal, it delivers "negative value", whereas the maximized manageable usage of POFA delivers "positive value" while decreases negative impacts on the environment. By comparing the palm-oil products during past two centuries, POFA has the most negative effects on the environment since it remains in the atmosphere. By burning the solid wastes as a fuel in a boiler, POFA will be produced [35]. The solid wastes are palm oil husk or fibre and palm kernel shell. The residue of an oil palm industry is shown in Figure 3a. By using $300 \mu \mathrm{m}$ of sieve, there are ashes remained which are displayed in Figure $3 \mathrm{~b}[\underline{36}]$. 


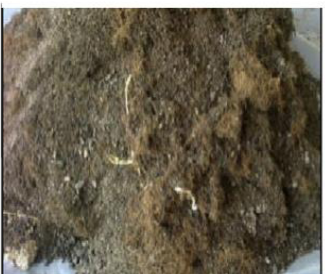

(a)

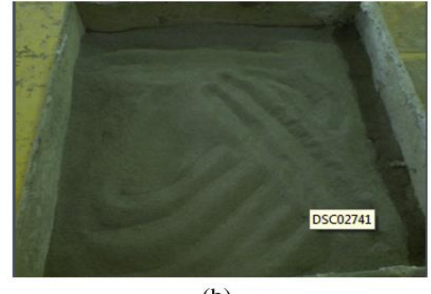

(b)
Figure 3. (a) Palm oil residue and (b) palm oil fuel ash [36].

The POFA has various development processes both in industrial development stage and burning process. The early stage preparation of POFA was tested by Noorvand et al. (2013) in an oven for the duration of 24 hours under $105 \pm 5{ }^{\circ} \mathrm{C}$ of temperature once the burning process was over [37]. On the other hand, Tangchirapat et al. (2009) have the ashes prepared after incineration process by using sieve number 16 (1.18 $\mathrm{mm}$ opening) under the temperature of 700 to $1000{ }^{\circ} \mathrm{C}$. According to their experimental studies, three types of POFA were found based on the gravity sizes of 1.89 for original (OP), 2.36 for medium (MP) and 2.43 as for the small (SP). Their analysis proves that the grinding process in addition of enhancing the POFA's quality, it improves the specific gravity too [35]. In 2013, Abdul Awal and Shehu (2013) conducted a research in Johor which is the southern-state of Malaysia. In this study the ashes were prepared from the flue tower's foot. Then, a $150 \mu \mathrm{m}$ of filter was used in sieving process. The results were grounded and modified to the Los Angeles abrasion test machine containing 10 stainless steel bars. These bars were having $12 \mathrm{~mm}$ diameter with $800 \mathrm{~mm}$ long and were used as a replacement for steel balls [38]. Depending on the carbon content of the ashes produced, their colors vary from light grey to dark grey [37, 39-44]. Finally, it was understood that the fuel industry is the main sources of the raw materials of the POFA, being incinerated in a boiler or other grinding industries. In addition, those fine ashes that were escaped from the boiler were trapped and sieved by a $150 \mu \mathrm{m}$ to $300 \mu \mathrm{m}$ filter so that the small sized ashes remain. The palm oil industry's operating system has direct effect on the POFA's physical characteristics. The Los Angeles abrasion test machine is used to ground the ash. This machine had 10-20 stainless steel bars. POFA had a grey color in bulk, but it became darker by the increment of the properties of the carbons that were unburned. Table 3 describes POFA's properties where silicon dioxide $\left(\mathrm{SiO}_{2}\right)$ is the core oxide. POFA has about $59.6 \%$ to $66.9 \%$ of silica. Furthermore, there is approximately $1.9 \%$ to $5.7 \%$ of iron as well as about $5 \%$ calcium oxide $(\mathrm{CaO})$. Nevertheless, it has a specific gravity of 1.9 to 2.4 . In addition, the carbon's amount exists in ash is effectively depends upon the incineration process. As an instance, the amount of Loss on Ignition was $8.25 \%$ which is considered high according to the ASTM C618 that specified it $6 \%$ as the maximum value [45]. Efficiency parameters such as time and temperature, combustion process and material source are the main reasons for having different amount of chemical components in POFA.

Table 3. The chemical and physical properties of POFA [지].

\begin{tabular}{|c|c|}
\hline \multicolumn{2}{|c|}{ Chemical composition (\%) } \\
\hline $\mathrm{SiO}_{2}$ & $59.6-66.9$ \\
\hline $\mathrm{Al}_{2} \mathrm{O}_{3}$ & $2.5-6.4$ \\
\hline $\mathrm{Fe}_{2} \mathrm{O}_{3}$ & $1.9-5.7$ \\
\hline $\mathrm{CaO}$ & $4.9-6.4$ \\
\hline $\mathrm{MgO}$ & $3.0-4.5$ \\
\hline $\mathrm{SO}_{3}$ & $0.3-1.3$ \\
\hline $\mathrm{Na}_{2} \mathrm{O}$ & $0.2-0.8$ \\
\hline $\mathrm{K}_{2} \mathrm{O}$ & $5.0-7.5$ \\
\hline LOI & $6.6-10.0$ \\
\hline \multicolumn{2}{|c|}{ Physical properties } \\
\hline Median particle size $(\mu m)$ & 10.5 \\
\hline Specific gravity & $1.9-2.4$ \\
\hline Blaine fineness $\left(\mathrm{m}^{2} / \mathrm{kg}\right)$ & 493.0 \\
\hline
\end{tabular}

Table 4. The selected mix proportion of high strength concrete. $[\underline{35}, \underline{38}, \underline{43}, \underline{44}, \underline{46}, 47]$.

\begin{tabular}{|c|c|c|c|c|c|c|c|c|c|c|c|}
\hline & Cement & $\begin{array}{l}\text { POFA } \\
\mathrm{kg} / \mathrm{m}^{3}\end{array}$ & $\%$ & Sand & $\begin{array}{c}\text { Coarse } \\
\text { aggregate }\end{array}$ & Water & SP (I) & $\mathbf{W} / \mathbf{C}$ & Slump & $\begin{array}{c}\text { Day } \\
28 \text { days }\end{array}$ & 90 days \\
\hline 1 & 495.0 & 55.0 & 10 & 753 & 959 & 176 & 6.8 & 0.32 & 250 & 60 & 68 \\
\hline 2 & 440.0 & 110.0 & 20 & 745 & 950 & 176 & 8.6 & 0.32 & 240 & 61 & 70 \\
\hline 3 & 385.0 & 165.0 & 30 & 738 & 940 & 176 & 11.6 & 0.32 & 250 & 59 & 66 \\
\hline 4 & 400.0 & 100.0 & 20 & 711 & 1067 & 145 & 11.5 & 0.28 & - & 37 & 52 \\
\hline 5 & 400.0 & 100.0 & 20 & 711 & 1067 & 145 & 11.5 & 0.28 & - & 49 & 53 \\
\hline 6 & 540.4 & 145.3 & 25 & 1057 & 1340 & 168 & 50.4 & 0.23 & 169 & 175 & 182 \\
\hline 7 & 214.0 & 213.0 & 50 & 787 & 961 & 205 & - & 0.29 & 115 & 41 & - \\
\hline 8 & 171.0 & 256.0 & 60 & 787 & 961 & 205 & - & 0.29 & 90 & 36 & - \\
\hline
\end{tabular}




\begin{tabular}{cccccccccccc}
\hline 9 & 128.0 & 299.0 & 70 & 787 & 961 & 205 & - & 0.29 & 80 & 28 & - \\
10 & 504.0 & 56.0 & 10 & 757 & 971 & 153 & 8.5 & 0.28 & 200 & 89 & 91 \\
11 & 448.0 & 112.0 & 20 & 749 & 962 & 151 & 11.8 & 0.28 & 185 & 94 & 93 \\
12 & 392.0 & 168.0 & 30 & 742 & 952 & 148 & 16.9 & 0.28 & 185 & 87 & 91 \\
13 & 270.0 & 30.0 & 10 & 804 & 1024 & 216 & - & 0.72 & 80 & 39 & 40 \\
14 & 240.0 & 60.0 & 20 & 801 & 1021 & 210 & - & 0.70 & 60 & 32 & 39 \\
15 & 210.0 & 90.0 & 30 & 799 & 1018 & 219 & - & 0.73 & 75 & 28 & 34 \\
\hline
\end{tabular}

The pazzolanic reaction of coarse POFA is slower as compared to high fineness POFA. Therefore, because of the higher dense and homogeneous of the high fineness POFA, it can effectively enhance the concrete's compressive strength. Moreover, POFA can be applied as a binder to meet the chemical necessities of the ASTM C618 [45]. Due to the low Loss of Ignition (LoI) of the POFA which is below $10 \%$, it will be used as a pazzolanic component. As a result, it benefits the concrete construction industry. As another research in concrete strength enhancements, the capabilities of POFA as a pozzolan were investigated [36]. There is a tremendous effort by the researches to improve the POFA concrete's behavior to the pazzolanic reactions where the result of this reaction is the hydration products. Table 4 displays the compressive strength of few chosen mixtures. The compressive strength of the concretes having different POFA's properties is over 55 MPA in 28-days test. However, by increasing the POFA percentage up to $20 \%$ and $30 \%$ in the concrete, the compressive strength is 59 and 61 MPA respectively. According to the Table 4, the concrete samples having POFA have higher compressive strength as compared to the normal concretes at 28 days. The compressive strength of a concrete increases to 70 MPA in 90-days test and by using $20 \%$ POFA. Two different palm oil industries provided two types of POFA which are CAPOFA and ALPOFA. Based on the sample G(I), utilizing fiber (steel) as a binder aggregate can lead to a compressive strength of 175 MPA in comparison with situations where no fibers are used. In the meantime, by having $10 \%, 20 \%$ and $30 \%$ of the POFA mixed with $10 \%$ $\mathrm{SF}$, the strength increases to $93 \mathrm{MPA}$. Moreover, to make a concrete with high strength, POFA with proportion of $30 \%$ can be applied in replacement of cement which results in higher compressive strength as compared to the concrete produced using Portland cement. The compressive strength has an expansion and loss which can be reduced if the ultrafine is included. It was proposed that to minimize the needs of the high-strength concrete to the water, POFA can be utilized to act like pazzolanic POFA [46]. In general, it has been proved that POFA has pazzolanic cementing materials including superior engineering in a suitable and appropriate mixing and curing system. In addition, the larger amount of waste materials produced in agriculture can be used. Then, by reducing the waste's volumes and Greenhouse Gases CO (GAGs), the environment will be protected. Besides, in addition of reducing the construction-cost, POFA is conducive to maintainable industry.
Recently, cellulose, lignin and hemicellulose which form the lignocellulosic materials of a palm oil fiber, have obtained the demand thrust. Therefore, the lignocelluloses fibers are obtainable and they are being heavily utilized even with inadequate developments in technology. The oil palm fiber is a harmless, recyclable material taken from Oil Palm's Empty Fruit Bunch (OPEFB) by applying a process called decortation. As the main specifications of the fibers can point to their cleanness, non-carcinogenic, soft parenchyma cells as well as free from insecticide. The fibers used in this study are displayed in Figure 4. As the purpose of making cost effective construction material in construction industry, the interests in using natural fibers as reinforcement have been dramatically increased [48]. The comparison between physical properties of the palm oil fibre and other references are explained in Table 5.

The mechanical properties of palm oil fiber like tensile strength, elongation and modulus of elasticity of fiber are shown in Table 6 . These properties were ascertained by the ASTM C1557 standards by using a Tinius Olsen machine and $8 \times 10-6 \mathrm{~m} / \mathrm{min}$ of cross-head speed. However, Subramani (2007) claims that specified fiber content (percentage) is the only factor affecting the compressive strength. In their study, by increasing the fiber content percentage, the modulus rupture of specimens remains constant. They reported that there might be a reduction in bonding and disintegration if the fiber is congested [49]. The lowest flexural strength of the specimen is when there are $0.5 \%$ of content and $5 \mathrm{~cm}$ of fiber length where the $5 \mathrm{~cm}$ fiber length could be the reason of this low flexural strength since majority of the fibers weaken the bonding among particles [미]. One of the vital components in a concrete is fiber's size. It has both pros and cons based upon the fiber's length size. However, in comparison with long fibers, small fibers deliver a uniform dispersion in the concrete mix if the concrete properties are fresh. In addition, by using short fibres, the workability of the concrete mix increased as a result of extreme fiber balling reduction [51]. The strength of the composites can be further improved in 28 days by having palm oil fiber added to the composites. However, it must be noted that although the fiber causes enhancements in the strength but this is not true for the fiber content (percentage) [49].

\subsection{Palm oil fibre}




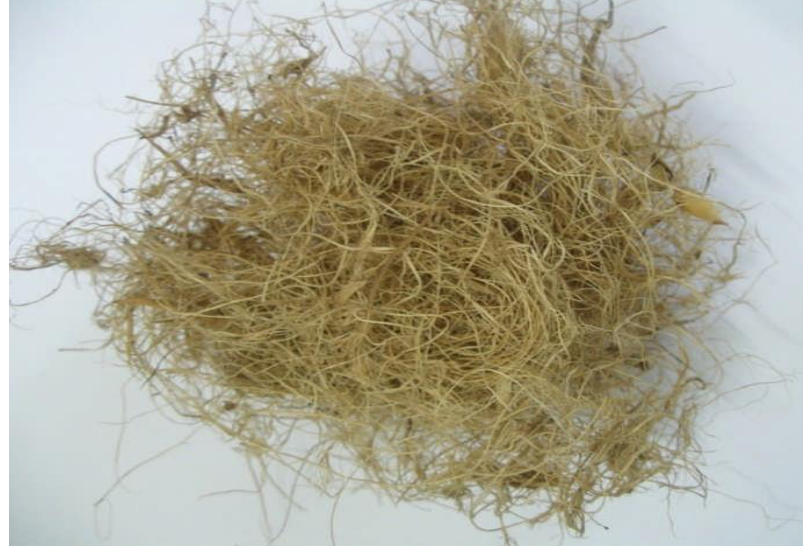

Figure 4. Palm Oil Fiber [묘]

Table 5. Mechanical Properties of POF [뇨].

\begin{tabular}{lccc}
\hline \multicolumn{1}{c}{ Technical } & Reference & \multicolumn{2}{c}{ Result from } \\
Attributes & [49, 52] & Amrec, & FKKKSA, \\
SIRIM & UTM \\
\hline $\begin{array}{l}\text { Tensile Strength } \\
\text { (MPA) }\end{array}$ & 21.2 & 83.1 & 113.43 \\
\hline $\begin{array}{l}\text { Elongation at } \\
\text { break (\%) }\end{array}$ & 0.04 & 0.11 & 0.11 \\
\hline $\begin{array}{l}\text { Compression of } \\
\text { Strength }\end{array}$ & 36.4 & - & - \\
\hline
\end{tabular}

\begin{tabular}{lccc}
\hline (MPA) & & & \\
\hline $\begin{array}{l}\text { Direct Screw } \\
\text { Withdrawal (N) }\end{array}$ & 1420 & - & - \\
\hline $\begin{array}{l}\text { Nail Withdrawal } \\
\text { (N) }\end{array}$ & 310 & - & - \\
\hline $\begin{array}{l}\text { Bending Stress } \\
\text { (MPA) }\end{array}$ & 37.6 & - & - \\
\end{tabular}

That means by the increase in fiber content (percentage), the strength does not necessarily improve. There could be an improvement on the strength of hardens concrete based on the fiber content. Yet, both the structural integrity of the harden concrete and bonding and disintegration can be reduced by the fiber congestion. By utilizing the fiber in concrete the matrix bonding will be increased in comparison with control mix. As a result, the concrete's strength improves. Once the fiber is added to the concrete, based upon its percentage as $0.25 \%$ or $0.50 \%$, the optimum length of the fiber would be $5 \mathrm{~cm}$ and $3 \mathrm{~cm}$ respectively. Therefore, by having the fiber content, the required properties increase [무]. Ramli and Dawood (2010) denoted that the addition of oil palm fibre in the mixture will moderately increase the density of the lightweight concrete [53].

Table 6. Physical Properties of Palm Oil Fiber [묘].

\begin{tabular}{|c|c|c|c|}
\hline \multirow{2}{*}{ Properties } & \multicolumn{2}{|l|}{ Result From } & References \\
\hline & MPOB/UKM & {$[\underline{54}]$} & [52] \\
\hline Average fiber length, $\mu m$ & 170.38 & - & - \\
\hline Average fiber width, $\mu m$ & 291.44 & - & - \\
\hline Average lumen width, $\mu m$ & 11.33 & 7.90 & 12.34 \\
\hline Average wall thickness, $\mu m$ & 4.90 & 2.30 & 3.38 \\
\hline Moisture content, $\%$ & 10.57 & - & - \\
\hline Ashes content, $\%$ & 2.4 & - & - \\
\hline Water absorption, $\%$ & 15.97 & , SIRI & \\
\hline
\end{tabular}

\section{CONCLUSION}

As long as the population grows, it is essential for the concrete industries to focus on the maintainable developments. Therefore, it is possible to reach to this objective by using by-products and agricultural wastes. According to the previous studies, some specific agricultural wastes such as oil palm shell, palm oil fuel ash and oil palm fibre can be used in producing the concrete due to their satisfactory performance. As a result, by using these materials, an initiative can be taken to enhance the environmental sustainability of the concrete industry. Hence, by the advances in current knowledge and exploration of the other agricultural wastes to be applied in concrete mixtures, there will be a feasible contribution in enhancements and improvements of the environmentally sustainable and friendly constructions. 


\section{ACKNOWLEDGEMENTS}

The authors gratefully acknowledge the financial support from Innovation and Management Center, project number SEGiIRF/2014-65/FoEBE-14/79, Segi University.

\section{REFERENCES}

[1] R. Swamy, Design for sustainable development of concrete construction, Proceedings of the Fourth International Structural Engineering and Construction Conference (ISEC 4), Taylor \& Francis Ltd England, 2007, pp. 47-54.

[2] C. Meyer, The greening of the concrete industry, Cement and Concrete Composites, 31 (2009) 601-605.

[3] R. Rosković, D. Bjegović, Role of mineral additions in reducing CO 2 emission, Cement and Concrete Research, 35 (2005) 974-978.

[4] P.K. Mehta, P.J. Monteiro, Concrete: microstructure, properties, and materials, McGraw-Hill New York2006.

[5] A. Ramezanianpour, M. Mahdikhani, G. Ahmadibeni, The effect of rice husk ash on mechanical properties and durability of sustainable concretes, DOI (2009).

[6] L. Federico, S. Chidiac, Waste glass as a supplementary cementitious material in concretecritical review of treatment methods, Cement and concrete composites, 31 (2009) 606-610.

[7] S. Badur, R. Chaudhary, Utilization of hazardous wastes and by-products as a green concrete material through S/S process: A review, Rev. Adv. Mater. Sci, 17 (2008) 42-61.

[8] M. Harimi, D. Harimi, V.J. Kurian, B. Nurmin, Evaluation of the Thermal Performance of Metal Roofing under Tropical Climatic Conditions, Center of Mineral and Materials, Universiti Malaysia Sabah, Malaysia, 2005.

[9] K. Miura, T. Masuda, T. Funazukuri, K. Sugawara, Y. Shirai, J.-i. Hayashi, M.I.A. Karim, F.N. Ani, H. Susanto, Efficient use of oil palm wastes as renewable resource for energy and chemicals, Kyoto University, Japan, March, DOI (2001).

[10] Global Palm Oil Conference, Colombia, 2015.

[11] U. ESCAP, ESCAP report: biomass increasingly important in Indonesia and Thailand, E-news environment and sustainable development, 7 (2007) 5.
[12] P. Shafigh, M.Z. Jumaat, H. Mahmud, Mix design and mechanical properties of oil palm shell lightweight aggregate concrete: a review, International journal of the physical sciences, 5 (2010) 2127-2134.

[13] M. Mannan, C. Ganapathy, Mix design for oil palm shell concrete, Cement and concrete research, 31 (2001) 1323-1325.

[14] F.O. Okafor, Palm kernel shell as a lightweight aggregate for concrete, Cement and Concrete Research, 18 (1988) 901-910.

[15] D. Okpala, Palm kernel shell as a lightweight aggregate in concrete, Building and environment, 25 (1990) 291-296.

[16] H. Basri, M. Mannan, M. Zain, Concrete using waste oil palm shells as aggregate, Cement and concrete Research, 29 (1999) 619-622.

[17] D. Teo, M.A. Mannan, V. Kurian, C.

Ganapathy, Lightweight concrete made from oil palm shell (OPS): structural bond and durability properties, Building and Environment, 42 (2007) 2614-2621.

[18] K. Gunasekaran, P. Kumar, M.

Lakshmipathy, Mechanical and bond properties of coconut shell concrete, Construction and building materials, 25 (2011) 92-98.

[19] M. Mannan, C. Ganapathy, Concrete from an agricultural waste-oil palm shell (OPS), Building and Environment, 39 (2004) 441-448.

[20] M.A. Mannan, C. Ganapathy, Engineering properties of concrete with oil palm shell as coarse aggregate, Construction and Building Materials, 16 (2002) 29-34.

[21] A. Abdullah, Basic strength properties of lightweight concrete using agricultural wastes as aggregates, Proceedings of international conference on low-cost housing for developing countries, Roorkee, India, 1984.

[22] P. Shafigh, M.Z. Jumaat, H. Mahmud, Oil palm shell as a lightweight aggregate for production high strength lightweight concrete, Construction and Building Materials, 25 (2011) 1848-1853.

[23] P. Shafigh, M.Z. Jumaat, H.B. Mahmud, U.J. Alengaram, A new method of producing high strength oil palm shell lightweight concrete, Materials \& Design, 32 (2011) 4839-4843.

[24] P. Shafigh, H. Mahmud, M.Z. Jumaat, Effect of steel fiber on the mechanical properties of oil palm shell lightweight concrete, Materials \& Design, 32 (2011) 3926-3932.

[25] P. Shafigh, H.B. Mahmud, M.Z. Jumaat, Oil palm shell lightweight concrete as a ductile material, Materials \& Design, 36 (2012) 650-654. [26] P. Shafigh, H.B. Mahmud, M.Z. Jumaat, M. Zargar, Agricultural wastes as aggregate in 
concrete mixtures-A review, Construction and Building Materials, 53 (2014) 110-117.

[27] D. Teo, M. Mannan, V. Kurian, Durability of lightweight OPS concrete under different curing conditions, Materials and structures, 43 (2010) 113.

[28] U.J. Alengaram, H. Mahmud, M.Z. Jumaat, Comparison of mechanical and bond properties of oil palm kernel shell concrete with normal weight concrete, DOI.

[29] B. Standard, 8110:'Structural use of concrete', British Standards Institution, DOI (1985).

[30] D.C. Teo, M.A. Mannan, J.V. Kurian, Flexural behaviour of reinforced lightweight concrete beams made with oil palm shell (OPS), Journal of Advanced Concrete Technology, 4 (2006) 459-468.

[31] E. Ahmed, H.R. Sobuz, Flexural and timedependent performance of palm shell aggregate concrete beam, KSCE Journal of Civil

Engineering, 15 (2011) 859-865.

[32] M.Z. Jumaat, U.J. Alengaram, H. Mahmud, Shear strength of oil palm shell foamed concrete beams, Materials \& Design, 30 (2009) 2227-2236. [33] U.J. Alengaram, M.Z. Jumaat, H. Mahmud, M.M. Fayyadh, Shear behaviour of reinforced palm kernel shell concrete beams, Construction and Building Materials, 25 (2011) 2918-2927. [34] D. Teo, M. Mannan, V. Kurian, Structural concrete using oil palm shell (OPS) as lightweight aggregate, Turkish Journal of Engineering and Environmental Sciences, 30 (2006) 251-257. [35] W. Tangchirapat, C. Jaturapitakkul, P. Chindaprasirt, Use of palm oil fuel ash as a supplementary cementitious material for producing high-strength concrete, Construction and Building Materials, 23 (2009) 2641-2646.

[36] E. Aprianti, P. Shafigh, S. Bahri, J.N. Farahani, Supplementary cementitious materials origin from agricultural wastes-A review, Construction and Building Materials, 74 (2015) 176-187.

[37] H. Noorvand, A.A.A. Ali, R. Demirboga, H. Noorvand, N. Farzadnia, Physical and chemical characteristics of unground palm oil fuel ash cement mortars with nanosilica, Construction and Building Materials, 48 (2013) 1104-1113. [38] A.A. Awal, I. Shehu, Evaluation of heat of hydration of concrete containing high volume palm oil fuel ash, Fuel, 105 (2013) 728-731.

[39] P. Chindaprasirt, C. Jaturapitakkul, T. Sinsiri, Effect of fly ash fineness on microstructure of blended cement paste, Construction and Building Materials, 21 (2007) 1534-1541.

[40] C. Jaturapitakkul, K. Kiattikomol, W.

Tangchirapat, T. Saeting, Evaluation of the sulfate resistance of concrete containing palm oil fuel ash, Construction and Building Materials, 21 (2007) 1399-1405.

[41] R. Madandoust, M.M. Ranjbar, H.A. Moghadam, S.Y. Mousavi, Mechanical properties and durability assessment of rice husk ash concrete, Biosystems engineering, 110 (2011) 144152.

[42] V. Sata, C. Jaturapitakkul, K. Kiattikomol, Utilization of palm oil fuel ash in high-strength concrete, Journal of Materials in Civil Engineering, 16 (2004) 623-628.

[43] V. Sata, C. Jaturapitakkul, K. Kiattikomol, Influence of pozzolan from various by-product materials on mechanical properties of highstrength concrete, Construction and Building Materials, 21 (2007) 1589-1598.

[44] W. Tangchirapat, C. Jaturapitakkul, Strength, drying shrinkage, and water permeability of concrete incorporating ground palm oil fuel ash, Cement and Concrete Composites, 32 (2010) 767774.

[45] C. Astm, 618 Standard Specification for Coal Fly Ash and Raw or Calcined Natural Pozzolan for use as a Mineral Admixture in Portland Cement Concrete, American Society for Testing of Materials, Philadelphia, USA, DOI.

[46] M. Aldahdooh, N.M. Bunnori, M.M. Johari, Development of green ultra-high performance fiber reinforced concrete containing ultrafine palm oil fuel ash, Construction and Building Materials, 48 (2013) 379-389.

[47] S. Bamaga, M. Hussin, M.A. Ismail, Palm oil fuel ash: promising supplementary cementing materials, KSCE Journal of Civil Engineering, 17 (2013) 1708-1713.

[48] M.A. El-Gelany Ismail, Study on the properties of palm oil fiber, DOI (2009).

[49] M. Subramani, Palm oil fiber as an additive in concrete, Universiti Teknologi Malaysia, DOI (2007).

[50] H. Hashim, The effect of palm oil fiber on concrete properties, Tesis Sarjana Muda. Universiti Teknologi Malaysia, 2008.

[51] Y. Mohammadi, S. Singh, S. Kaushik, Properties of steel fibrous concrete containing mixed fibres in fresh and hardened state, Construction and Building Materials, 22 (2008) 956-965.

[52] K.-N. Law, W.R.W. Daud, A. Ghazali, Morphological and chemical nature of fiber strands of oil palm empty-fruit-bunch (OPEFB), BioResources, 2 (2007) 351-362.

[53] M. Ramli, E.T. Dawood, Effects of palm fiber on the mechanical properties of lightweight 
concrete crushed brick, Am J Eng Appl Sci, 3

(2010) 489-493.

[54] A.K. Mohanty, M. Misra, L.T. Drzal, Natural

fibers, biopolymers, and biocomposites, CRC

Press2005. 